\begin{tabular}{ccc}
\hline & International Journal of Engineering \& Technology, 7 (2.27) (2018) 238-243 \\
SPC & Website $w$ ww.sciencepubco.com/index.php/IJET \\
Research paper & Technology \\
\hline
\end{tabular}

\title{
Implementation of fuzzy analytical hierarchy process on notebook selection
}

\author{
Satria Abadi ${ }^{1}$, Miftachul Huda ${ }^{2}$, Bushrah Basiron ${ }^{2}$, Siti Suhaila Ihwani ${ }^{2}$, Kamarul Azmi Jasmi ${ }^{2}$ \\ Aminudin Hehsan ${ }^{2}$, Jimaain Safar ${ }^{2}$, Ahmad Kilani Mohamed ${ }^{2}$, Wan Hassan Wan Embong ${ }^{2}$, \\ Ahmad Marzuki Mohamad ${ }^{2}$, Sulaiman Shakib Mohd Noor ${ }^{2}$, Dona Novita ${ }^{1}$, \\ Andino Maseleno ${ }^{1,3 *}$, Rita Irviani ${ }^{1}$, Muhammad Idris ${ }^{4}$, \\ Muhamad Muslihudin ${ }^{1}$ \\ ${ }^{1}$ Department of Information Systems, STMIK Pringsewu, Lampung, Indonesia \\ ${ }^{2}$ Faculty of Social Sciences and Humanities, Universiti Teknologi Malaysia, Malaysia \\ ${ }^{3}$ Institute of Informatics and Computing Energy, Universiti Tenaga Nasional, Malaysia \\ ${ }^{4}$ Department of Islamic Education Management, STIT Pringsewu, Lampung, Indonesia \\ *Corresponding author E-mail: andimaseleno@gmail.com
}

\begin{abstract}
Notebooks are technological devices widely adopted to assist in human daily life including learning, business, communication and other tasks. Equipped with the distinctive features, notebook was facilitated more simply for one touch screen basis to enable freely in exploring the users' creativity. This study attempts to examine the process of selecting notebook brand among the consumers. Using AHP (Analytical Hierarchy Process) to help decision support system in the selection of Notebook from decision support systems designed to enhance all decision-process through identifying problems, selecting relevant data and defining the approaches was used to evaluate the selection of alternatives in the decision-making process. The finding reveals that the visibility of decision making into the ranking of priority with alternative choice of notebook can be viewed as follows Zyrex 16\%, HP 15\%, Asus 14\%, Apple 13\%, Samsung and Axioo $11 \%$, Acer and Toshiba with priority $10 \%$.
\end{abstract}

Keywords: Decision Support System; AHP; Notebook; Fuzzy

\section{Introduction}

The latest technology market from Canalys revealed that worldwide notebook shipments in the second quarter of 2014 have jumped to 49.1 million units. Sales of tablet devices fell about five percent to 48.4 million units [1-4]. According to Canalys, for the first time since the third quarter of 2013, notebook shipments have surpassed tablets. From the statement is known that people's interest to use the notebook quite a lot [5-8]. In Indonesia alone, there are many options notebook brand, so there is a difficult for consumers in choosing a notebook. Starting from the many brands, specifications, notebook features are offered and consumer confusion in prioritizing the factors that affect the selection of notebooks [9-12].

Research conducted utilization of Analytical Hierarchy Process method with PHP programming language as decision support system can help admin give recommendation to buyer more quickly, effective and transparent [13-16]. Decision making system can provide information about advantages and disadvantages of alternative laptop products choice and can provide decisions for multimedia students by using the method of Simple Additive Weight [17-20].

In the selection of laptops by giving five criteria, then research with objects and with different methods [21-24]. The difference with the research that has been done is designing Decision Support System Selection Notebook Using Analytical Hierarchy Process
Method by providing six criteria [25-28]. Thus, there can be used in the implementation of decision support system for the selection of notebooks that can help customers in choosing a notebook that suits their needs and this research also aims to know whether the decision support system notebook selection using AHP method can help consumers in choosing a notebook that suits the needs and budget costs.

\section{Theoretical review}

\subsection{Decision support system}

Decision Support System is an interactive information system that provides information, modeling, and data manipulation. The system is used to assist decision making in semi-structured situations and unstructured situations, where no one knows for sure how decisions should be made [29-32].

\subsection{Analytical hierarchy process}

AHP is a practical approach to solving complex decision problems that include alternative comparisons. AHP also allows decision making to present a hierarchical relationship between factors, attributes, characteristics or alternatives in the decision-making environment. With special features, the hierarchy it possesses, unstructured complex problems solved in groups [33-36]. 
In its application, the use of AHP methods in decision making has several advantages and disadvantages. The advantages of the AHP method are:

a) Can solve complex problems, and the structure is irregular, even the problem is not structured at all.

b) Lack of written data or quantitative data on issues does not affect the smoothness of the decision-making process because the assessment is a synthesis of thoughts from various perspectives of respondents.

c) In accordance with the basic human capabilities in assessing a matter so as to facilitate the assessment and measurement of elements.

d) Methods are equipped with consistency testing so as to provide guarantees of decisions to be taken.

While the weakness of the AHP method:

a) Dependency on the main input. This key input is the perception of a decision maker, so in this case it involves the subjectivity of the decision maker. In addition, this model is meaningless if the decision-maker is wrong in providing an assessment.

b) This method is mathematical in the absence of statistical testing so that there is no limit to the beliefs of truth that is formed.

c) The users involved should have sufficient knowledge and experience on AHP issues and methods [37-40].

\subsection{Notebook}

Notebook is a small portable computer and light weight of 2-6 kg depending on size, materials, and specifications. The power source uses an A/C adapter to recharge the battery and turn on the notebook [41-44]. Notebooks are technological tools that are widely selected to assist in the execution of tasks from school or office tasks [45-48]. The form is simple and practical and equipped with some interesting features make notebook users are increasingly given the freedom to more freely become more creative in pouring ideas creative owned.

\section{Research methodology}

\subsection{Data collection method}

Methods of data collection in this study are:

a) The method of literature is the collection of data by reading and studying literature or books related to the research undertaken, in this research is a book decision support system, AHP method, and other books in accordance with the problems.

b) Interview method of this method is done to collect data by asking a number of questions, the authors conducted interviews with the marketing department of computer stores about the data notebook available.

c) Observation method of data collection techniques where the author relies on observations directly, in this study the authors visited the computer store to get data about the notebook and then draw conclusions from the observations.

\subsection{Analytical hierarchy process method}

Basically, the procedures or steps in the AHP method include[15]:

1) Commitment to follow a particular action

2) Determining the priority of the element:

a) The first step in determining the priority of the elements to make a pair comparison comparing the elements in pairs according to given criteria;

b) A pairwise comparison matrix filled with numbers to represent the relative importance of an element against other elements.

3) Synthesis
The things in step to considerations for paired comparisons in synthesis to obtain overall priority or Total Priority Value (TPV) are:

a) Sums up the values of each column in the matrix.

b) Divide each value of the column by the corresponding column total to obtain the normalization of the matrix.

c) Sums up the values of each row and divides it by the number of elements (n) to get the average value (TPV).

4) Measuring Consistency

Consider low consistency. Things to do in steps in making decisions, it is important to know how good the consistency is because we do not want a decision based on this:

a) Multiply each value in the first column with the relative priority of the first element, the value in the second column with the relative priority of the second element and so on.

b) Amount each row

c) The result of the sum of rows is divided by the relevant relative priority element (TPV).

d) Sum it up with the number of elements that exist, the result is called $\lambda$ maks.

$\lambda$ maks $=(\lambda$ maks K1....$+++\Lambda$ maks Kn $) / \mathrm{n}$

Information:

$\lambda$ maks $=$ the average value of the entire criterion

$\mathrm{n}=$ number of criteria in comparison matrix.

Calculate Consistency Index (CI) with the formula:

1) Define the problem and determine the desired solution, then compile the hierarchy of the problems encountered. The preparation of the hierarchy is to set goals that are the overall system objectives at the top level.

2) Calculate Consistency Ratio (CR)

By the formula: $\mathrm{CR}=\mathrm{CI} / \mathrm{IR}$

Where CR = Consistency Ratio

$\mathrm{CI}=$ Consistency Index

$\mathrm{IR}=$ Index Random

3) Criteria and Alternative Assessment (Comparative Judgment)

Criteria and alternatives are assessed through pairwise comparisons. According to Saaty [17], for various issues, the scale 1 to 9 is the best scale in expressing opinions. Scale $1-9$ is set as a consideration in comparing the pairs of elements at each hierarchical level to an element at the top level.

Comparisons are made on the basis of the policy of the decision maker by assessing the importance of one element to the other. The pairwise comparison process starts from the topmost hierarchy level aimed at selecting criteria, such as A1, A2, and A3. Then the composition of the compared elements will look like in the matrix table 1 below.

\begin{tabular}{lllll}
\multicolumn{5}{c}{ Table 1: Matrik } \\
\hline C & A1 & A2 & A3 & A4 \\
\hline A1 & 1 & 2 & 3 & 4 \\
A2 & $1 / 2$ & 1 & $\ldots$ & $\ldots$ \\
A3 & $1 / 3$ & $\ldots$ & 1 & $\ldots$ \\
A4 & $1 / 4$ & $\ldots$ & $\ldots$ & 1 \\
\hline
\end{tabular}

4) Priority Determination

In decision making, the thing to note is when the data is expected to be close to the real value. The degree of customer interest can be made by paired comparison approach. Pairwise Comparison is often used to determine the relative importance of the elements of the criteria. 
From each pairwise comparison matrix can be determined eigenvector value to get priority area (local priority). Because the pairwise comparison matrix exists at every level, the global priority can be obtained by synthesizing among the priorities of the region.

$\mathrm{CI}=\frac{\lambda \operatorname{maks}-\mathrm{n}}{\mathrm{n}-1}$

Where $\mathrm{n}=$ the number of elements

Formulated as follows:

$\underline{\mathrm{CR}}=\mathrm{CI}$

Where

$\mathrm{CR}=$ Consistency Ratio

$\mathrm{CI}=$ Consistency Index

$\mathrm{RI}=$ Random Index

To verify whether the above approach is true, it will calculate the value of CR (Consistency Ratio), where CR $<0.1$ get a valid value as shown in table 2 .

Table 2: Consistency Ration

\begin{tabular}{ll}
\hline Matrix Size & Value (IR) \\
\hline 1,2 & 0.00 \\
Matrix Size & Value (IR) \\
3 & 0.58 \\
4 & 0.90 \\
5 & 1.12 \\
6 & 1.24 \\
7 & 1.32 \\
8 & 1.41 \\
9 & 1.45 \\
10 & 1.49 \\
11 & 1.51 \\
12 & 1.48 \\
13 & 1.56 \\
14 & 1.57 \\
15 & 1.59 \\
\hline
\end{tabular}

5) Priority Weight

The result of paired AHP comparisons in priority weights reflecting the relative importance of elements in the hierarchy. There are three types of priority weights are:

a) Local Priority Weights (LPW), states the relative importance of an element compared to its core.

b) Average Priority Weights (APW), states the relative importance of an element compared to a set of core.

c) Global Priority Weights (GPW), states the relative importance of an element to the overall goal [16-17].

Criteria Used

In this study the variables used are:
1) Price
2) Weight
3) Processor
4) RAM
5) Memory
6) Hard disk

Alternative tested

As for the alternative products tested are:

1) Acer

2) HP

3) Apple

4) Asus

5) Toshiba

6) Samsung

7) Axio

\section{8) Zyrex}

Weigth Value

The table 3 and table 4 below are the calculation to be included to calculate the comparison between the criteria. Each criterion has a different level of importance.

Table 3: AHP Interest Rating

\begin{tabular}{ll}
\hline Value of Interest Criteria & Convert to value AHP \\
\hline unimportant (TP) & 1 \\
Not too important (KP) & 3 \\
important (P) & 5 \\
too important (SP) & 7 \\
Absolutely Important (MP) & 9 \\
\hline
\end{tabular}

Table 4: Rating of Interest Criteria

\begin{tabular}{ll}
\hline Value of Interest Criteria & Convert to value AHP \\
\hline Weight (TP) & 1 \\
Memory (P) & 5 \\
Processor (P) & 5 \\
RAM (SP) & 7 \\
Price (MP) & 9 \\
Hard disk (SP) & 7
\end{tabular}

\subsection{Research thinking framework}

Research Framework is Flowchart Decision Support System Selection of Notebook Analytical Hierarchy Process Method. The process of making a study is to make a preliminary, theoretical basis, determine the method of research, discuss and analyze the results of research, the last concluded the results of research.

\section{Analysis and discussion}

Based on the explanation of the steps of the AHP method above, it will be calculated the selection of Notebook with alternative selected notebook is Acer, HP, Apple, Asus, Toshiba, Samsung, Axioo, Zyrex. While the selected criteria are price, weight, processor, RAM, Memory, and hard disk.

The first step is to create a pairwise comparison table. Pairwise comparisons are made from the very first row of a pairwise paired matrix, for example in the first row there is a price criterion with a ratio of $9 / 9=1$ because they both have an Absolute Value (MP) value criterion that equals 9 . Then the price criterion (MP) is compared to the weight criteria (TP) $9 / 1=9$. Then the price criterion (MP) is compared to the processor criterion (P) $9 / 5=1.8$, and further until each row of criteria on the table has been compared and got the value of each comparison.

The final result determines the most superior alternative in the election decision support system as shown in table 5 .

Table 5: End Result of Notebook Selection

\begin{tabular}{|c|c|c|c|c|c|c|c|}
\hline \multicolumn{8}{|c|}{ Result of end calculation } \\
\hline & $\begin{array}{l}\text { Pric } \\
\mathrm{e}\end{array}$ & $\begin{array}{l}\text { Weig } \\
\text { ht }\end{array}$ & $\begin{array}{l}\text { Process } \\
\text { or }\end{array}$ & $\begin{array}{l}\mathrm{Ra} \\
\mathrm{m}\end{array}$ & $\begin{array}{l}\text { Memor } \\
\mathrm{y}\end{array}$ & $\begin{array}{l}\text { Harddi } \\
\text { sk }\end{array}$ & $\begin{array}{l}\mathrm{Re}- \\
\text { sult }\end{array}$ \\
\hline Weight & 0,26 & 0,03 & 0,15 & $\begin{array}{l}0,2 \\
1\end{array}$ & 0,15 & 0,21 & \\
\hline Acer & 0,12 & 0,1 & 0,13 & $\begin{array}{l}0,0 \\
2\end{array}$ & 0,09 & 0,12 & $10 \%$ \\
\hline Нр & 0,12 & 0,1 & 0,18 & $\begin{array}{l}0,1 \\
5\end{array}$ & 0,15 & 0,16 & $15 \%$ \\
\hline Apple & 0,02 & 0,15 & 0,24 & $\begin{array}{l}0,1 \\
5\end{array}$ & 0,29 & 0,05 & $13 \%$ \\
\hline Asus & 0,16 & 0,15 & 0,13 & $\begin{array}{l}0,1 \\
5\end{array}$ & 0,09 & 0,16 & $14 \%$ \\
\hline $\begin{array}{l}\text { Toshib } \\
\text { a }\end{array}$ & 0,12 & 0,15 & 0,08 & $\begin{array}{l}0,0 \\
7\end{array}$ & 0,09 & 0,12 & $10 \%$ \\
\hline $\begin{array}{l}\text { Samsu } \\
\text { ng }\end{array}$ & 0,16 & 0,15 & 0,08 & $\begin{array}{l}0,0 \\
7\end{array}$ & 0,09 & 0,12 & $11 \%$ \\
\hline Axioo & 0,16 & 0,05 & 0,08 & $\begin{array}{l}0,0 \\
7\end{array}$ & 0,09 & 0,16 & $11 \%$ \\
\hline Zyrek & 0,16 & 0,15 & 0,08 & $\begin{array}{l}0,3 \\
3 \\
\end{array}$ & 0,09 & 0,09 & $16 \%$ \\
\hline
\end{tabular}


Calculation of the final result by calculating the priority of Acer $=$ $(0,21 \times 0,26)+(0,10 \times 0,03)+(0,13 \times 0,15)+(0,02 \times 0,21)+$ $(0.09 \times 0.15)+(0.12 \times 0.21)=0.10=10 \%$ and so on. From the results of calculations performed and supported by the determination of predetermined criteria, it is known that the most superior notebook alternative is Zyrek with the highest value of 0.16 or $16 \%$ then it can be said Zyrek as a choice of best notebook as shown in figure 1 .

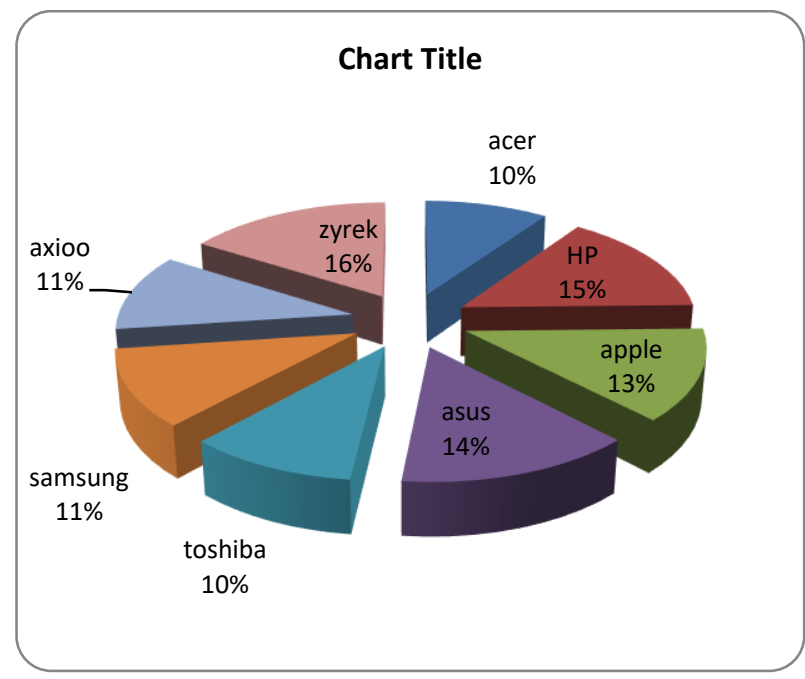

Fig. 1: Priority Graph of Selected Notebook Quality.

Notebook was considered as the particular trends of technological devices widely adopted to assist in human daily life including learning, business, communication and other tasks. Equipped with the distinctive features, notebook was facilitated more simply for one touch screen basis to enable freely in exploring the users' creativity [49-52]. Emerging trends in maximizing notebook was enlarged with the skills of personalized behavior to commit with measurement on subject expertise [53-56]. It should be pointed out the way to manage in contributing the learning analytic in strengthening the way of enhancing this initiative [57-60], to achieve the initial value of with Analytical Hierarchy Process method [61-64]. Enhancing the innovative approach on determination in selection process into the product through the interaction along with interactive and innovative basis [65-68] aims the sense that refers to an exposure towards decision making using Analytical Hierarchy Process method. In particular, the strategic initiative of application through incorporating the wide range of approaches [69-72] refers to the particular attention in obtaining the basic involvement using the procedural context [73] in line with gaining the core component in achieving the good appointment. Through expanding the valuable contribution into the process itself, an innovative approach with a significant attribution could be enhanced using an insightful performance into the strategic promotion initiative.

\section{Conclusion}

From the results of the test with Analytical Hierarchy Process method of notebook selection using Analytical Hierarchy Process method and using six criteria that is price, weight, processor, RAM, memory, harddisk then get the result rank order is Zyrex with priority $16 \%$, HP 15\%, Asus 14\%, Apple 13\%, Samsung and Axioo $11 \%$, Acer and Toshiba with priority $10 \%$ so it can be expressed research using AHP method is effective and efficient.

\section{References}

[1] Y. Saputra, "Decision Support System for Selection Laptop with Analytical Hierarchy Process (AHP)," Skripsi UNDINUS, pp. 1-8, 2015 .
[2] H. Yustriandi and Y. A. Elisabet, "Sistem Pendukung Keputusan Memilih Laptop Untuk Mahasiswa Multimedia Menggunakan Metode Simple Additive Weight (SAW)," KMSI, vol. 5, no. 1, pp. $1-5,2017$.

[3] G. P. Sanyoto, R. I. Handayani, and E. Widanengsih, "Sistem Pendukung Keputusan Pemilihan Laptop Untuk Kebutuhan Operasional Dengan Metode Ahp (Studi Kasus: Direktorat Pembinaan Kursus Dan Pelatihan Kemdikbud)," J. Pilar Nusa Mandiri, vol. 13, no. 2, pp. 167-174, 201.

[4] E. Turban, J. E. Aronson, and T.-P. Liang, "Decision Support Systems and Intelligent Systems,” Decis. Support Syst. Intell. Syst., vol. 7, p. 867, 2007.

[5] M. Muslihudin, A. Latif, S. Ipnuwati, R. Wati, and A. Maseleno, "A Solution to Competency Test Expertise of Engineering Motorcycles using Simple Additive Weighting Approach," Int. J. Pure Appl. Math., vol. 118, no. 7, pp. 261-267, 2018.

[6] M. Muslihudin, T. S. Susanti, A. Maseleno, and S. Pringsewu, "The Priority of Rural Road Development using Fuzzy Logic based Simple Additive Weighting," Int. J. Pure Appl. Math., vol. 118, no. 8, pp. 9-16, 2018 .

[7] Sunarto and R. Asmara, "Sistem Pendukung Keputusan Pemilihan Handphoone Metode Analytical Heriarchy Process (AHP) Berbasis PHP," Politek. Elektron. Negeri Surabaya, pp. 1-5, 2011.

[8] S. K. Patil and R. Kant, "A fuzzy AHP-TOPSIS framework for ranking the solutions of Knowledge Management adoption in Supply Chain to overcome its barriers," Expert Syst. Appl., vol. 41, no. 2, 2014. https://doi.org/10.1016/j.eswa.2013.07.093.

[9] S. W. Satria Abadi, "The Model of Determining Quality of Management Private Higher Education Using FAHP (Fuzzy Analytic Hierarchy Process) Method," ICESIA 1, vol. 1, no. 1, pp. 166-172, 2016.

[10] S. S. Hanung Wibowo, Wawan Lakisto, "Sistem Pendukung Keputusan Pembelian Handphone Dengan Metode Analytical Hierarchy Process," Tikomsin, vol. 1, no. 1, pp. 1-9, 2013.

[11] M. Rizqi, A. Akbar, Y. Fitrian, and A. Maseleno, "Dismissal Working Relationship using Analytic Hierarchy Process Method,” Int. J. Pure Appl. Math., vol. 118, no. 7, pp. 177-184, 2018.

[12] T. Susilowati, E. Y. Anggraeni, W. Andewi, Y. Handayani, and A. Maseleno, "Using Profile Matching Method to Employee Position Movement," Int. J. Pure Appl. Math., vol. 118, no. 7, pp. 415-423, 2018.

[13] P. Prianggara, "Sistem pendukung keputusan rekomendasi pemilihan Notebook dengan Metode Weighted Product Berbasis Web," Skripsi UMS, pp. 1-21, 2017.

[14] H. Purwanto, "Sistem Penunjang Keputusan Pemilihan Notebook dengan Menggunakan Metode Topsis," J. Ilmu Pengetah. Dan Teknol. Komput. vol. 2, no. 2, pp. 55-59, 2017.

[15] C. B. Andrianto, Kusrini, and H. Al Fatta, "Analisis Sistem Pendukung Keputusan Penerima Beasiswa Di Smp Muhammadiyah 2 Kalasan,” J. Teknol. Inf., vol. XII, no. 34, pp. 46-60, 2017.

[16] J. A. Palma-Mendoza, "Analytical hierarchy process and SCOR model to support supply chain re-design," Int. J. Inf. Manage., vol. 34, no. 5, pp. 634-638, 2014. https://doi.org/10.1016/j.ijinfomgt.2014.06.002.

[17] T. L. Saaty, "The Analytic Hierarchy Process," Education, pp. 1-11, 1980.

[18] A. Maseleno, M. M. Hasan, M. Muslihudin, and T. Susilowati, "Finding Kicking Range of Sepak Takraw Game: Fuzzy Logic and Dempster-Shafer Theory Approach," Indones. J. Electr. Eng. Comput. Sci., vol. 2, no. 1, p. 187, 2016. https://doi.org/10.11591/ijeecs.v2.i1.pp187-193.

[19] A. Maseleno, N. Tuah, and C. R. Tabbu, "Fuzzy Logic and Dempster-Shafer Theory to Predict the Risk of Highly Pathogenic Avian Influenza H5n1 Spreading Computer Science Program , Universiti Brunei Darussalam , Faculty of Veterinary Medicine, Gadjah Mada University , Indonesia," World Appl. Sci. J., vol. 34, no. 8, pp 995-1003, 2016.

[20] Maseleno, A., Huda, M., Siregar, M., Ahmad, R., Hehsan, A., Haron, Z., Ripin, M.N., Ihwani, S.S., and Jasmi, K.A. (2017). Combining the Previous Measure of Evidence to Educational Entrance Examination. Journal of Artificial Intelligence 10(3), 85-90 https://doi.org/10.3923/jai.2017.85.90.

[21] Maseleno, A., Pardimin, Huda, M., Ramlan, Hehsan, A., Yusof, Y.M., Haron, Z., Ripin, M.N., nor, N.H.M., and Junaidi, J. (2018a). Mathematical Theory of Evidence to Subject Expertise Diagnostic. ICIC Express Letters, 12 (4), 369 DOI: 10.24507/icicel.12.04.369

[22] Huda, M., Maseleno, A., Muhamad, N.H.N., Jasmi, K.A., Ahmad, A., Mustari, M.I., Basiron, B. (2018a). Big Data Emerging Technology: Insights into Innovative Environment for Online Learning 
Resources. International Journal of Emerging Technologies in Learning 13(1), 23-36. https://doi.org/10.3991/ijet.v13i01.6990.

[23] Huda, M., Teh, K.S.M., Nor, N.H.M., and nor, M.B.M. (2018b). Transmitting Leadership Based Civic Responsibility: Insights from Service Learning. International Journal of Ethics and Systems, 34(1), 20-31. https://doi.org/10.1108/IJOES-05-2017-0079.

[24] Huda, M. (2018). Empowering Application Strategy in the Technology Adoption: Insights from Professional and Ethical Engagement. Journal of Science and Technology Policy Management. https://doi.org/10.1108/JSTPM-09-2017-0044.

[25] Anshari, M., Almunawar, M. N., Shahrill, M., Wicaksono, D. K., \& Huda, M. (2017). Smartphones usage in the classrooms: Learning aid or interference. Education and Information Technologies, 22(6), 3063-3079. https://doi.org/10.1007/s10639-017-9572-7.

[26] Huda, M., Shahrill, M., Maseleno, A., Jasmi, K. A., Mustari, I., \& and Basiron, B. (2017a). Exploring Adaptive Teaching Competencies in Big Data Era. International Journal of Emerging Technologies in Learning, 12(3), 68-83. https://doi.org/10.3991/ijet.v12i03.6434 0.

[27] Maseleno, A., Huda, M., Jasmi, K.A., Mustari, M.I., and Basiron, B (2018). Understanding Learning Analytics to Improve Personalised Learning. International Journal of Engineering and Technology. (In press). https://doi.org/10.14419/ijet.v7i3.9789.

[28] Huda, M., Maseleno, A., Jasmi, K. A., Mustari, I., \& Basiron, B. (2017c). Strengthening Interaction from Direct to Virtual Basis: Insights from Ethical and Professional Empowerment. International Journal of Applied Engineering Research, 12(17), 6901-6909.

[29] Othman, R., Shahrill, M., Mundia, L., Tan, A., \& Huda, M. (2016). Investigating the Relationship between the Student's Ability and Learning Preferences: Evidence from Year 7 Mathematics Students. The New Educational Review, 44(2), 125-138.

[30] Huda, M., Haron, Z., Ripin, M. N., Hehsan, A., \& Yaacob, A. B. C. (20171). Exploring Innovative Learning Environment (ILE): Big Data Era. International Journal of Applied Engineering Research, 12(17), 6678-6685.

[31] Huda, M., Jasmi, K. A., Mustari, M. I., Basiron, B., Mohamed, A. K., Embong, W. \& Safar, J. (2017g). Innovative E-Therapy Service in Higher Education: Mobile Application Design. International Journal of Interactive Mobile Technologies, 11(4), 83-94. https://doi.org/10.3991/ijim.v11i4.6734.

[32] Huda, M., Jasmi, K. A., Hehsan, A., Shahrill, M., Mustari, M. I., Basiron, B., \& Gassama, S. K. (2017b). Empowering Children with Adaptive Technology Skills: Careful Engagement in the Digital Information Age. International Electronic Journal of Elementary Education, 9(3), 693-708.

[33] Adela, H., Jasmi, K.A., Basiron, B., Huda, M., Maseleno, A. (2018). Selection of dancer member using simple additive weighting. International Journal of Engineering \& Technology. 7(3). 1096-1107. https://doi.org/10.14419/ijet.v7i3.11983.

[34] Aminin, S., Huda, M., Ninsiana, W., and Dacholfany, M.I. (2018) Sustaining civic-based moral values: Insights from language learning and literature. International Journal of Civil Engineering and Technology. 9(4), 157-174.

[35] Amin, M.M., Nugratama, M.A.A., Maseleno, A., Huda, M., Jasmi, K.A., (2018). Design of cigarette disposal blower and automatic freshner using mq-5 sensor based on atmega 8535 microcontroller. International Journal of Engineering \& Technology. 7(3). 11081113. https://doi.org/10.14419/ijet.v7i3.11917.

[36] Atmotiyoso, P. and Huda, M. (2018). Investigating Factors Influencing Work Performance on Mathematics Teaching: A Case Study. International Journal of Instruction. 11(3), 391-402 https://doi.org/10.12973/iji.2018.11327a.

[37] Huda, M., \& Teh, K. S. M. (2018). Empowering Professional and Ethical Competence on Reflective Teaching Practice in Digital Era. In Dikilitas, K., Mede, E., Atay D. (Eds). Mentorship Strategies in Teacher Education (pp. 136-152). Hershey, PA: IGI Global. https://doi.org/10.4018/978-1-5225-4050-2.ch007.

[38] Huda, M., Teh, K.S.M., Nor, N.H.M., and nor, M.B.M. (2018a). Transmitting Leadership Based Civic Responsibility: Insights from Service Learning. International Journal of Ethics and Systems, 34(1), 20-31. https://doi.org/10.1108/IJOES-05-2017-0079.

[39] Huda. M. \& Sabani, N. (2018). Empowering Muslim Children's Spirituality in Malay Archipelago: Integration between National Philosophical Foundations and Tawakkul (Trust in God). International Journal of Children's Spirituality, 23(1), 81-94. https://doi.org/10.1080/1364436X.2018.1431613.

[40] Huda, M., Qodriah, S.L., Rismayadi, B., Hananto, A., Kardiyati, E.N., Ruskam, A., and Nasir, B.M. (2018). Towards Cooperative with Competitive Alliance: Insights into Performance Value in Social Entrepreneurship in Creating Business Value and Competitive
Advantage with Social Entrepreneurship. (pp.294). Hershey, PA: IGI Global.

[41] Huda, M., Hehsan, A., Basuki, S., Rismayadi, B., Jasmi, K. A., Basiron, B., \& Mustari, M. I. (2019). Empowering Technology Use to Promote Virtual Violence Prevention in Higher Education Context. In Intimacy and Developing Personal Relationships in the Virtual World (pp. 272-291). Hershey, PA: IGI Global. https://doi.org/10.4018/978-1-5225-4047-2.ch015.

[42] Huda, M., Ulfatmi, Luthfi, M.J., Jasmi, K.A., Basiron, B., Mustari, M.I., Safar, A., Embong, H.W.H., Mohamad, A.M., and Mohamed, A.K. (2019). Adaptive online learning technology: Trends in big data era in Diverse Learning Opportunities Through TechnologyBased Curriculum Design. Hershey, PA: IGI Global. (In press).

[43] Kurniasih, D., Jasmi, K.A., Basiron, B., Huda, M., Maseleno, A. (2018). The uses of fuzzy logic method for finding agriculture and livestock value of potential village. International Journal of Engi$\begin{array}{llll}\text { neering } \& \quad \text { Technology. } & \text { 7(3). }\end{array}$ https://doi.org/10.14419/ijet.v7i3.11984.

[44] Maseleno, A., Huda, M., Jasmi, K.A., Basiron, B., Mustari, I., Don, A.G., and Ahmad, R. (2018b). Hau-Kashyap approach for student's level of expertise. Egyptian Informatics Journal, https://doi.org/10.1016/j.eij.2018.04.001.

[45] Maseleno, A., Sabani, N., Huda, M., Ahmad, R., Jasmi, K.A., Basiron, B. (2018c). Demystifying Learning Analytics in Personalised Learning. International Journal of Engineering \& Technology. 7(3). 1124-1129. https://doi.org/10.14419/ijet.v7i3.9789.

[46] Moksin, A. I., Shahrill, M., Anshari, M., Huda, M., \& Tengah, K. A (2018b). The Learning of Integration in Calculus Using the Autograph Technology. Advanced Science Letters, 24(1), 550-552. https://doi.org/10.1166/asl.2018.12067.

[47] Putra, D.A.D., Jasmi, K.A., Basiron, B., Huda, M., Maseleno, A., Shankar, K., Aminudin, N. (2018). Tactical Steps for EGovernment Development. International Journal of Pure and Applied Mathematics.119 (15). 2251-2258

[48] Rosli, M.R.B., Salamon, H.B., and Huda, M. (2018). Distribution Management of Zakat Fund: Recommended Proposal for Asnaf Riqab in Malaysia. International Journal of Civil Engineering and Technology 9(3), pp. 56-64.

[49] Sugiyarti, E., Jasmi, K.A., Basiron, B., Huda, M., Shankar, K., Maseleno, A. (2018). Decision support system of scholarship grantee selection using data mining. International Journal of Pure and Applied Mathematics.119 (15), 2239-2249.

[50] Sundari, E., Jasmi, K.A., Basiron, B., Huda, M., and Maseleno, A. (2018). Web-Based Decision Making System for Assessment of Employee Revenue using Weighted Product. International Journal of Engineering and Technology.

[51] Susilowati, T., Jasmi, K.A., Basiron, B., Huda, M., Shankar, K., Maseleno, A., Julia, A., Sucipto. (2018). Determination of Scholarship Recipients Using Simple Additive Weighting Method. International Journal of Pure and Applied Mathematics.119 (15), 22312238.

[52] Huda, M., Sabani, N., Shahrill, M., Jasmi, K. A., Basiron, B., \& Mustari, M. I. (2017a). Empowering Learning Culture as Student Identity Construction in Higher Education. In A. Shahriar, \& G. Syed (Eds.), Student Culture and Identity in Higher Education (pp. 160-179). Hershey, PA: IGI Global. https://doi.org/10.4018/978-15225-2551-6.ch010.

[53] Huda, M., Jasmi, K. A., Basiran, B., Mustari, M. I. B., \& Sabani, A. N. (2017d). Traditional Wisdom on Sustainable Learning: An Insightful View from Al-Zarnuji's Ta 'lim al-Muta 'allim. SAGE Open, 7(1), 1-8. https://doi.org/10.1177/2158244017697160.

[54] Huda, M., Jasmi, K. A., Embong, W. H., Safar, J., Mohamad, A. M., Mohamed, A. K., Muhamad, N. H., Alas, Y., \& Rahman, S. K. (2017e). Nurturing Compassion-Based Empathy: Innovative Approach in Higher Education. In M. Badea, \& M. Suditu (Eds.), Violence Prevention and Safety Promotion in Higher Education Settings (pp. 154-173). Hershey, PA: IGI Global. https://doi.org/10.4018/978-1-5225-2960-6.ch009.

[55] Huda, M., Jasmi, K. A., Alas, Y., Qodriah, S. L., Dacholfany, M. I., \& Jamsari, E. A. (2017f). Empowering Civic Responsibility: Insights from Service Learning. In S. Burton (Ed.), Engaged Scholarship and Civic Responsibility in Higher Education (pp. 144-165). Hershey, PA: IGI Global. https://doi.org/10.4018/978-1-5225-36499.ch007.

[56] Huda, M., Jasmi, K. A., Mustari, M. I., \& Basiron, B. (2017h). Understanding Divine Pedagogy in Teacher Education: Insights from Al-zarnuji's Ta'lim Al-Muta'Allim. The Social Sciences, 12(4), 674-679. 
[57] Huda, M., Jasmi, K. A., Mustari, M. I. B., \& Basiron, A. B. (2017i). Understanding of Wara' (Godliness) as a Feature of Character and Religious Education. The Social Sciences, 12(6), 1106-1111.

[58] Huda, M., Siregar, M., Ramlan, Rahman, S.K.A., Mat Teh, K.S., Said, H., Jamsari, E.A., Yacub, J., Dacholfany, M.I., \& Ninsiana, W. (2017j). From Live Interaction to Virtual Interaction: An Exposure on the Moral Engagement in the Digital Era. Journal of Theoretical and Applied Information Technology, 95(19), 4964-4972.

[59] Huda, M., Anshari, M., Almunawar, M. N., Shahrill, M., Tan, A., Jaidin, J. H., \& Masri, M. (2016a). Innovative Teaching in Higher Education: The Big Data Approach. The Turkish Online Journal of Educational Technology, 15(Special issue), 1210-1216.

[60] Huda, M., Yusuf, J. B., Jasmi, K. A., \& Nasir, G. A. (2016b). Understanding Comprehensive Learning Requirements in the Light of al-Zarnūjī's Ta‘līm al-Muta'allim. Sage Open, 6(4), 1-14. https://doi.org/10.1177/2158244016670197.

[61] Huda, M., Yusuf, J. B., Jasmi, K. A., \& Zakaria, G. N. (2016c). AlZarnūjī's Concept of Knowledge ('ilm). SAGE Open, 6(3), 1-13. https://doi.org/10.1177/2158244016666885.

[62] Huda, M., Jasmi, K. A., Mohamed, A. K., Wan Embong, W. H., \& and Safar, J. (2016d). Philosophical Investigation of Al-Zarnuji's Ta'lim al-Muta'allim: Strengthening Ethical Engagement into Teaching and Learning. Social Science, 11(22), 5516-551.

[63] Wulandari, Aminin, S., Dacholfany, M.I., Mujib, A., Huda, M., Nasir, B.M., Maseleno, A., Sundari, E., Fauzi, Masrur, M., Design of Library Application System. International Journal of Engineering and Technology (UAE) (In Press).

[64] Susilowati, T., Teh, K.S.T., Nasir, B.M., Don, A.G.,Huda, M., Hensafitri, T., Maseleno, A., Oktafianto, Irawan, D. Learning Application of Lampung Language Based on Multimedia Software. International Journal of Engineering and Technology (UAE) (In Press).

[65] Abadi, S., Teh, K.S.M., Nasir, B.M., Huda, M., Ivanova, N.L., Sari, T.I., Maseleno, A., Satria, F., Muslihudin, M. Application Model of K-Means Clustering Insights into Promotion Strategy of Vocational High School. International Journal of Engineering and Technology (UAE) (In Press).

[66] Susilowati, T., Dacholfany, M.I., Aminin, S., Ikhwan, A., Nasir, B.M., Huda, M., Prasetyo, A., Maseleno, A., Satria, F., Hartanto, S., Wulandari. Getting Parents Involved in Child's School: Using Attendance Application System Based on SMS Gateway. International Journal of Engineering and Technology (UAE) (In Press).

[67] Aminudin, N., Huda, M., Ihwani, S.S., Noor, S.S.M., Basiron, B. Jasmi, K.A., Safar, J., Mohamed, A.K., Embong, W.H.W., Mohamad, A.M., Maseleno, A., Masrur, M., Trisnawati, Rohmadi, D. The Family Hope Program using AHP Method. International Journal of Engineering and Technology (UAE) (In Press).

[68] Aminudin, N., Fauzi, Huda, M., Hehsan, A., Ripin, M.N., Haron, Z., Junaidi, J., Irviani, R., Muslihudin, M., Hidayat, S., Maseleno, A., Gumanti, M., Fauzi, A. Application Program Learning Based on Android for Students' Experiences. International Journal of Engineering and Technology (UAE) (In Press).

[69] Abadi, S., Teh, K.S.M., Huda, M., Hehsan, A., Ripin, M.N., Haron, Z., Muhamad, N.H.N., Rianto, R., Maseleno, A., Riki, Syarif. Design of student score application for assessing the most outstanding student at vocational high school. International Journal of Engineering and Technology (UAE) (In Press).

[70] Aminudin, N., Huda, M., Kilani, A., Embong, W.H.W., Mohamed, A.M., Basiron, B., Ihwani, S.S., Noor, S.S.M., Jasmi, K.A., Safar, J., Ivanova, N.L., Maseleno, A., Triono, A., Nungsiati. Higher Education Selection using Simple Additive Weighting. International Journal of Engineering and Technology (UAE) (In Press).

[71] Anggraeni, E.Y., Huda, M., Maseleno, A., Safar, J., Jasmi, K.A., Mohamed, A.K., Hehsan, A., Basiron, B., Ihwani, S.S., Embong, W.H.W., Mohamad, A.M., Noor, S.S.M., Fauzi, A., Wijaya, D.A., Masrur, M. Poverty Level grouping using SAW Method. International Journal of Engineering and Technology (UAE) (In Press).

[72] Abadi, S., Huda, M., Jasmi, K.A., Noor, S.S.M., Safar, J., Mohamed, A.K., Embong, W.H.W., Mohamad, A.M., Hehsan, A., Basiron, B., Ihwani, S.S., Maseleno, A., Muslihudin, M., Satria, F., Irawan, D., Hartati, S. Determination of the Best Quail Eggs using Simple Additive Weighting. International Journal of Engineering and Technology (UAE) (In Press).

[73] Abadi, S., Huda, M., Hehsan, A., Mohamad, A.M., Basiron, B., Ihwani, S.S., Jasmi, K.A., Safar, J., Mohamed, A.K., Embong, W.H.W., Noor, S.S.M., Brahmono, B., Maseleno, A., Fauzi, A., Aminudin, N., Gumanti, M. Design of online transaction model on traditional industry in order to increase turnover and benefits. International Journal of Engineering and Technology (UAE) (In Press). 